\title{
Selecting insects as flagship species for Beverin Nature Park in Switzerland - a survey of local school children on their attitudes towards butterflies and other insects
}

\author{
Gabriele B. Breuer, Jürg Schlegel \& Reto Rupf
}

Keywords: environmental education, flagship species, insects, survey

\section{Abstract}

The management of Swiss Beverin Nature Park in the Canton of Grisons is interested in establishing insects as flagship species to promote the Schams Mountain (Schamserberg) ecosystem and wants to base the decision-making process on quantitative research.

A survey on attitudes towards insects was designed and then completed by 331 local pupils, aged 8 to 16. The standardized questionnaire presented 11 adult butterflies/ moths, 4 caterpillars and 7 other insects individually in colour photographs and asked how pretty, interesting, disgusting or fear-inducing the species were. Additionally, the underlying reasons for the reaction in terms of an animal's colour, pattern, body feature or movement and sound were sought.

The results add details to existing research and can serve as helpful information for both the creation of environmental education programmes and the selection of resident insects as flagship species. The expected positive perception of butterflies/moths was confirmed, while other insects were perceived as interesting and, if colourful, even pretty. In general, children noticed colour details. For levels of disgust, body features were important, while colour and pattern were largely irrelevant. As attitudes differed and tended to become more negative with higher-age participants, it is recommended that environmental education starts early and is target-group specific. Most of the insect species studied might serve as appropriate flagship species, based on their prettiness or the interest they attract. The final choice should also reflect the accessibility of their actual habitat. As a next step, Beverin Nature Park is advised to conduct further focused research on the specific distribution of the potential flagship insects within the park. On this basis, appropriate nature trails could be established with emphasis on environmental education.
Profile

Protected area

Beverin Nature Park

Mountain range

Alps

Country

Switzerland

\section{Introduction}

\section{Motivation}

The management of Beverin Nature Park in Switzerland has considerable interest in nature conservation. They aim to sustainably manage biodiversity and focus on entire ecosystems, including their ecological processes. To gain support, targeted approaches towards the local residents and school children are considered important stepping stones. As part of their communication and environmental education strategy, the park management wants to establish insects as flagship species for the respective habitats. This approach is in line with current research (Schlegel et al. submitted; Dennis et al. 2007; Munoz 2007; Simberloff 1998) where the importance of local flagship species, insects as flagship species, communication and environmental education strategies as well as ecosystem approaches are discussed in detail.

\section{State of the art}

The park management's strategy is fueled by the trend in nature conservation to use flagship species as communication and marketing tools (Walpole \& Lead-
er-Williams 2002; Samways et al. 1995). Increasingly, invertebrates and especially insects are considered appropriate and necessary flagship species (Barua et al. 2012; Guiney \& Oberhauser 2008), not only to support their own conservation as major contributors to biodiversity (Mora et al. 2011; Black et al. 2001; Hammond 1995), but also to enhance awareness of their contribution to ecosystem services (Losey \& Vaughan 2008).

The park management therefore asked the authors to conduct a quantitative survey involving the local schools in order to establish which insect species were feasible candidates as flagship species in terms of being pretty and interesting while not triggering disgust or fear. As prerequisites the species should (i) have a German common name without negative connotations (Shardlow 2013; Berenbaum 2008; Bowen-Jones \& Entwistle 2002), (ii) be local (Genovart et al. 2013), (iii) play an important ecological role (Shardlow 2013), (iv) allow for direct encounters (Barua et al. 2012), and (v) be endangered or rare (Knegtering et al. 2002). Prerequisites (ii) and (iii) ensure that the species chosen have particular habitat preferences, making them suitable representatives of the Beverin habitats. 


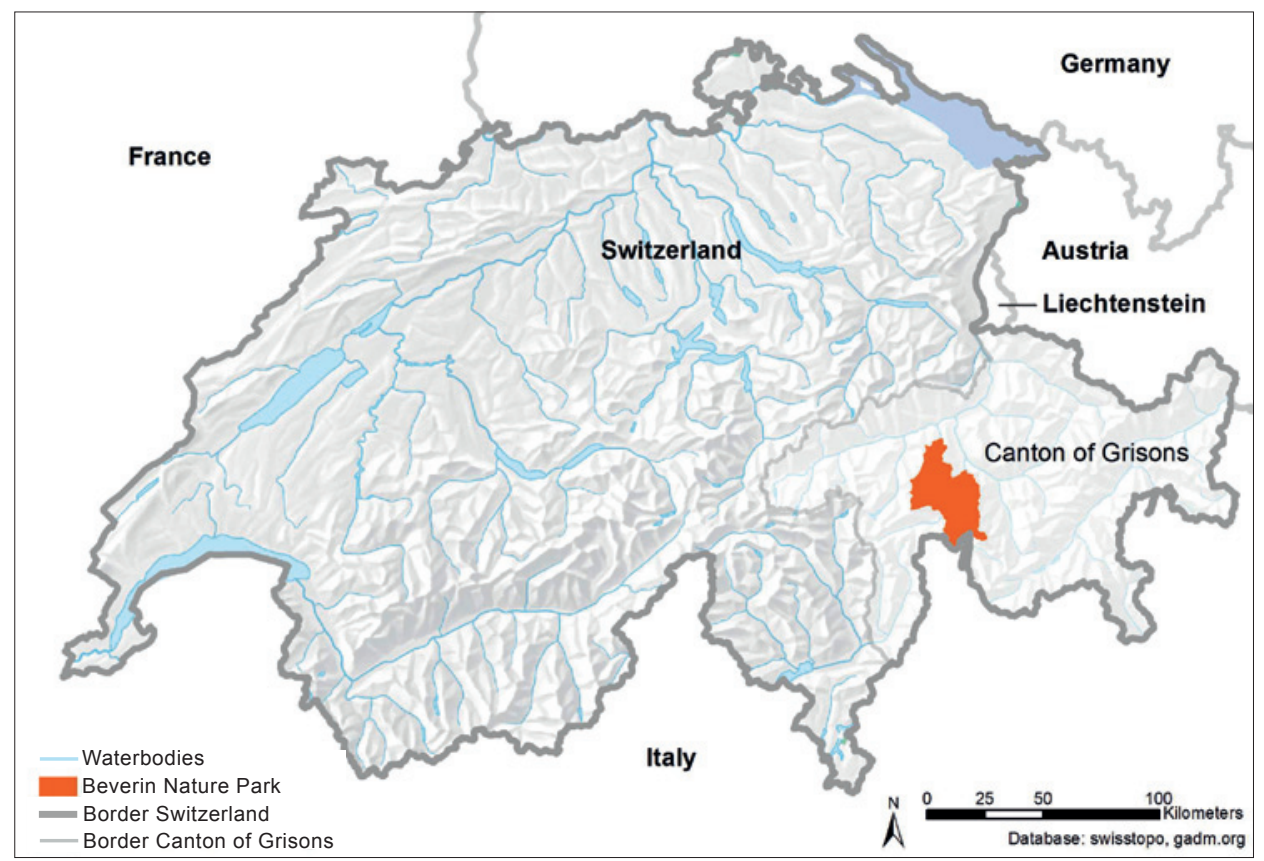

Figure 1 - Location of Beverin Nature Park in Switzerland, Canton of Grisons (area $373 \mathrm{~km}^{2}$ ).

Bednar et al. (2009) discuss the willingness to pay as an important aspect in nature conservation; in their view the use of flagship species offers only a marginal contribution to biodiversity conservation in Alpine ecosystems. They chose two birds as test species. Insects, on the other hand, seem to have the capacity for both, to serve as flagship species and to contribute to biodiversity conservation in Alpine ecosystems. Hence our paper focusses on this aspect as this was the task given by park management. A comprehensive discussion of mammals, birds and insects as possible flagship species is given by Schlegel \& Rupf (2010).

\section{Methods}

Beverin Nature Park in Switzerland includes 11 communities with around 2500 people. It spreads across $373 \mathrm{~km}^{2}$ in the Canton of Grisons (Figure 1). Besides its forests, wet meadows, floodplains and fens, its dry and poor grasslands are of special importance. These extensively managed dry meadows and pastures cover $5.6 \mathrm{~km}^{2}$, of which Schams Mountain (Schamserberg) is the largest and most prominent area (Forster et al. 2008) and locally well known.

Principals and teachers of 75 classes at 20 schools in the Beverin catchment area were contacted, a cover letter signed by the Beverin park management being included. 22 classes at 8 schools responded, resulting in the participation of 331 pupils. The 164 boys and 167 girls were $3^{\text {rd }}$ to $9^{\text {th }}$ graders, aged 8 to 16 (mean 12.19 yrs, S.D 2.16 yrs). The 175 children aged $8-12$ (mean $10.4 \mathrm{yrs}$, S.D. $1.2 \mathrm{yrs}$ ) were defined as pre-teens, while the 156 children aged 13-16 (mean $14.2 \mathrm{yrs}$, S.D. $0.9 \mathrm{yrs}$ ) were specified as teenagers.
The responding schools were primary and secondary schools. In Switzerland various types and levels of secondary schools exist (Realschule, Sek A, Sek B). However, in the region where our survey took place, some schools entertain mixed levels within one class for a given grade. Our aim was to receive responses from the actual local young population, we were not interested to test for influence of intelligence, previous knowledge or type of secondary school attended.

The standardized questionnaire presented 22 separate colour photographs of 11 adult butterflies / moths (below referred to as butterflies) and 11 other insects, i.e. 4 butterfly and moth caterpillars, 2 dragon fly species, 2 grasshopper species, 1 neuroptera species, 1 longhorn beetle species, and 1 bumblebee species (Table 1). All species are found in Beverin Nature Park, based on data provided by the Swiss Biological Records Center (Centre Suisse de Cartographie de la Faune - CSCF), the oldest dating from 1989 (bumblebee species Bombus mesomelas) and 1998 (Scarlet Tiger Moth Callimorpha dominula). The species were selected to represent the various habitats while displaying different colours, patterns and body shapes. Also needed was a German common name and, ideally, inclusion of the species in the Swiss Red Lists of endangered animal species (Wermeille et al. 2014; Monnerat et al. 2007; Gonseth and Monnerat 2002; Gonseth 1994).

The questionnaires, designed for easy comprehension, were sent to the participating schools in paper form. Each class received half of the forms with the species in reverse order to counter-balance potential effects of weariness. The forms were filled in during lessons. The teachers were instructed only to answer pupils' questions related to the proper understanding of the forms. 

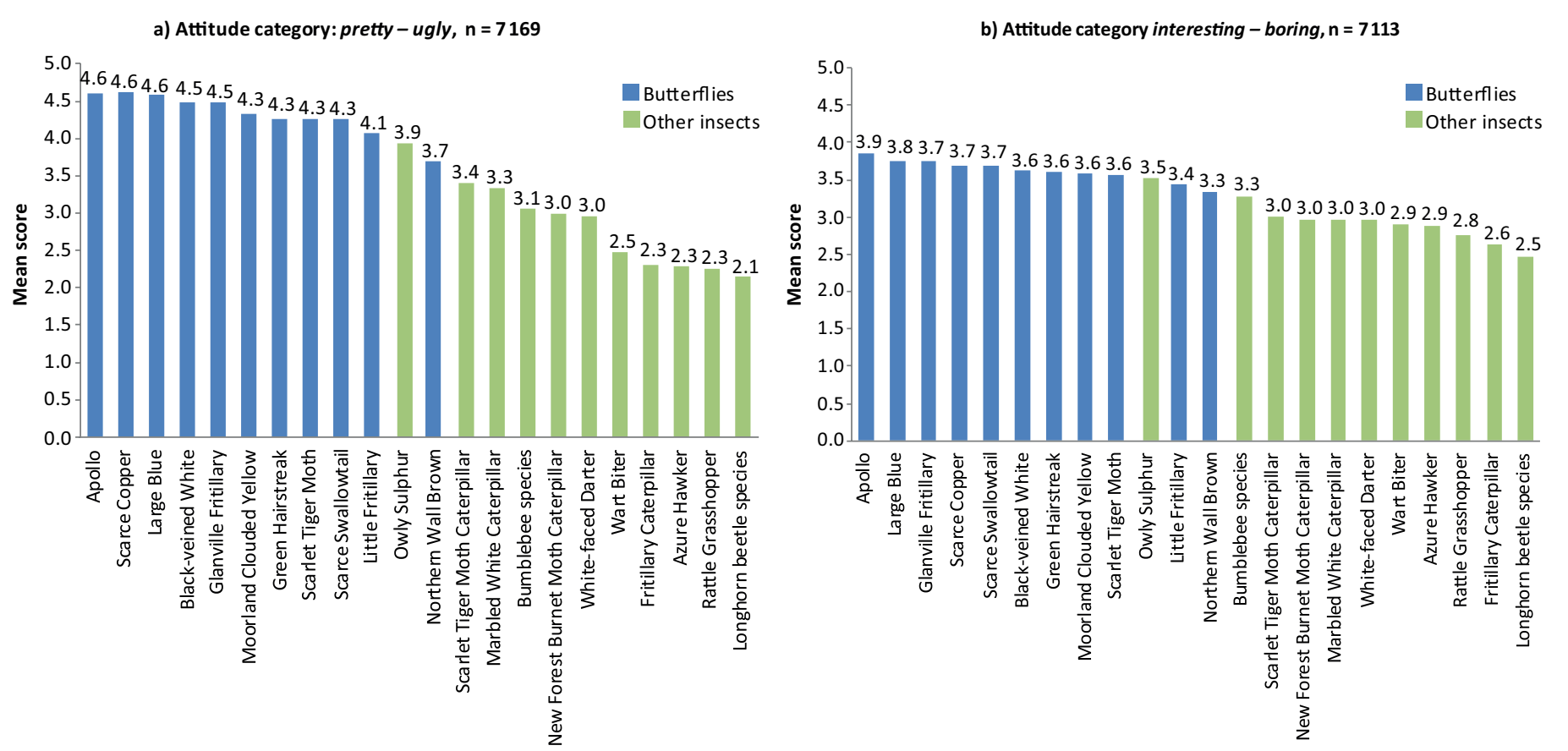

Figure 2 - Ranking of 22 species by mean score value (y-axis) in the categories pretty - ugly (a), interesting - boring (b), with 5 being the most positive and 1 being the most negative value. Ranking based on 331 questionnaires for 22 insects, with 7169 responses in the category pretty - ugly and 7113 responses in the category interesting - boring.

The pupils had to rate each species on an ordinal 5 -point Likert scale in 4 categories. To analyse the data, scores were assigned: very positive $=5$, fairly positive $=4$, neutral $=3$, fairly negative $=2$, very negative $=$ 1. However, to allow for equidistant response only the outer boxes were labelled as follows:

- very pretty - very ugly [sehr schön - sehr hässlich],

- very interesting - very boring [sehr interessant - sehr langweilig7,

- very pleasant on my hand - very disgusting on my hand [sehr angenehm auf meiner Hand - sehr eklig auf meiner Hand],

- I am very comfortable with this animal - I am very afraid of this animal Ich habe grosses Zutrauen zu diesem Tier - Ich habe grosse Angst vor diesem Tier].

The phrasing of the labels had been discussed with a teacher and the questionnaire pre-tested with 12 children aged 8-16 (mean age 11.75 yrs, S.D. 2.13 yrs). The categories chosen are based on current literature, where disgust is aroused through touch (Miller 1997; Herz 2012) and comfort used as an opposite of fear (Weiss 2012).

The pupils were also asked to give the reason for their score per category. They could choose between colour, pattern, body (form, hair, legs, wings) and movement / sound, and place up to 4 ticks. Where colour was a reason in any of the categories, the major colour was indicated.

Although treating ordinal Likert scales as numerical data is controversial (Lant 2013; Jamieson 2004), it is commonly done in research (Lindemann-Matthies 2006). We assumed equidistance to calculate the means for the attitude categories and tested the resulting rankings for correctness using Wilcoxon and KruskalWallis rank sum tests as the data does not follow a normal distribution. The Wilcoxon rank sum test was also applied to establish the effects of gender, age group (pre-teen vs teenager) and differences between pairs of insects. Significant differences were accepted with $\mathrm{p}<0.05$. The statistical analysis was performed in the $\mathrm{R}$ statistical environment ( $\mathrm{R}$ Foundation of Statistical Computing 2013).

\section{Results}

The high response rate (29\% of the teachers) was most likely due to the close involvement of the Beverin park management, the positive reputation of the park, and subsequent great willingness to support the park management's aims. With 331 questionnaires, split almost evenly between male and female, as well as pre-teen and teenage respondents, we consider our results solid and meaningful. The sample size is in line with or higher than similar studies (Schlegel et al. submitted; Randler et al. 2012; Balmford et al. 2002; Ballouard et al. 2001).

The species' mean values were ranked by category, with butterflies coming first in all categories and forming their own cohort. However, the Owly Sulphur (Libelloides coccajus) with its butterfly shaped wings managed to sneak in with the butterflies in the pretty 
Table 1 - List of the 22 insects evaluated, including their Swiss Red List* status, sorted alphabetically by scientific name within biological order (adult Lepidoptera, pre-imaginal Lepidoptera, Neuroptera, Hymenoptera, Orthoptera, Odonata, Coleoptera).

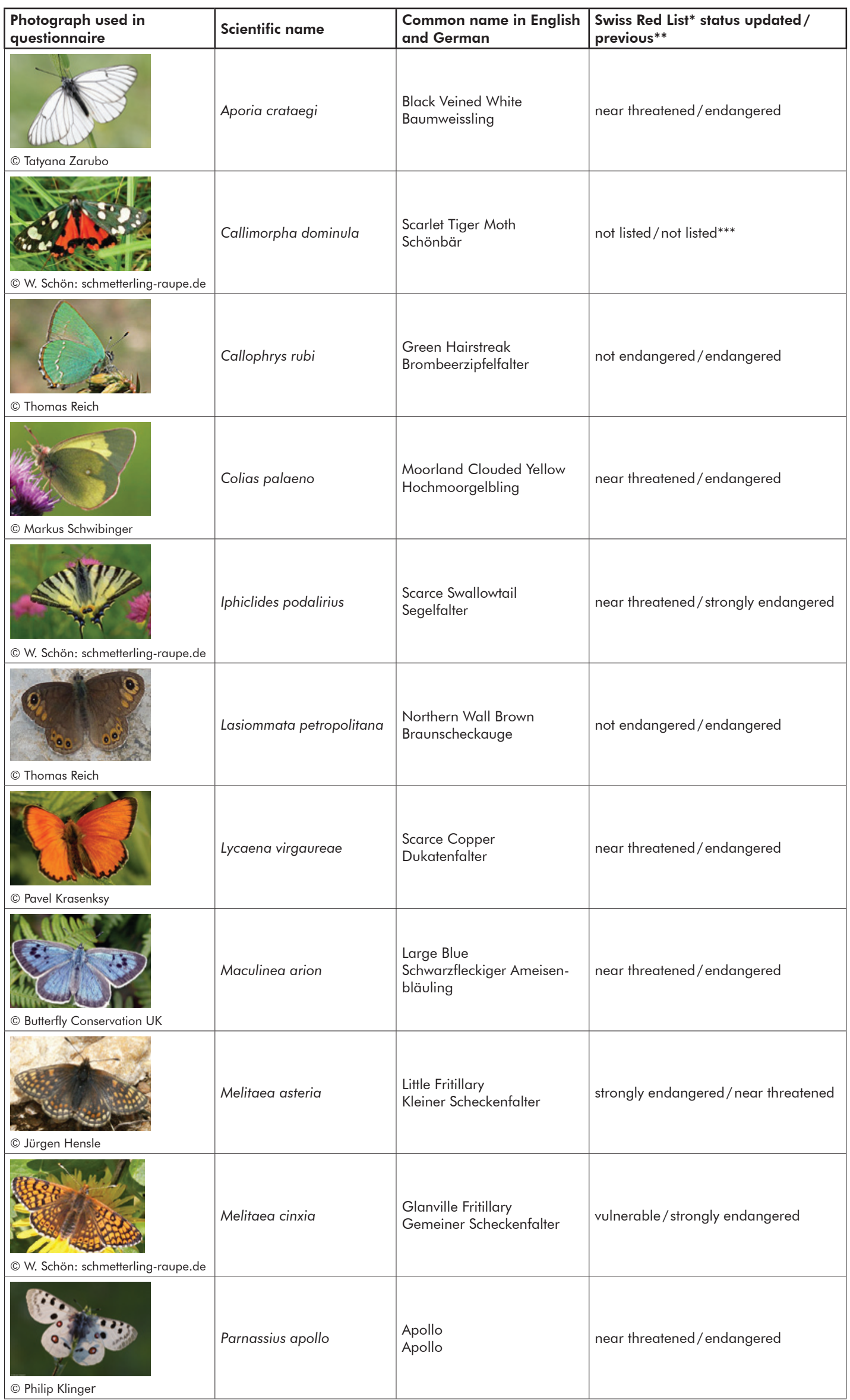




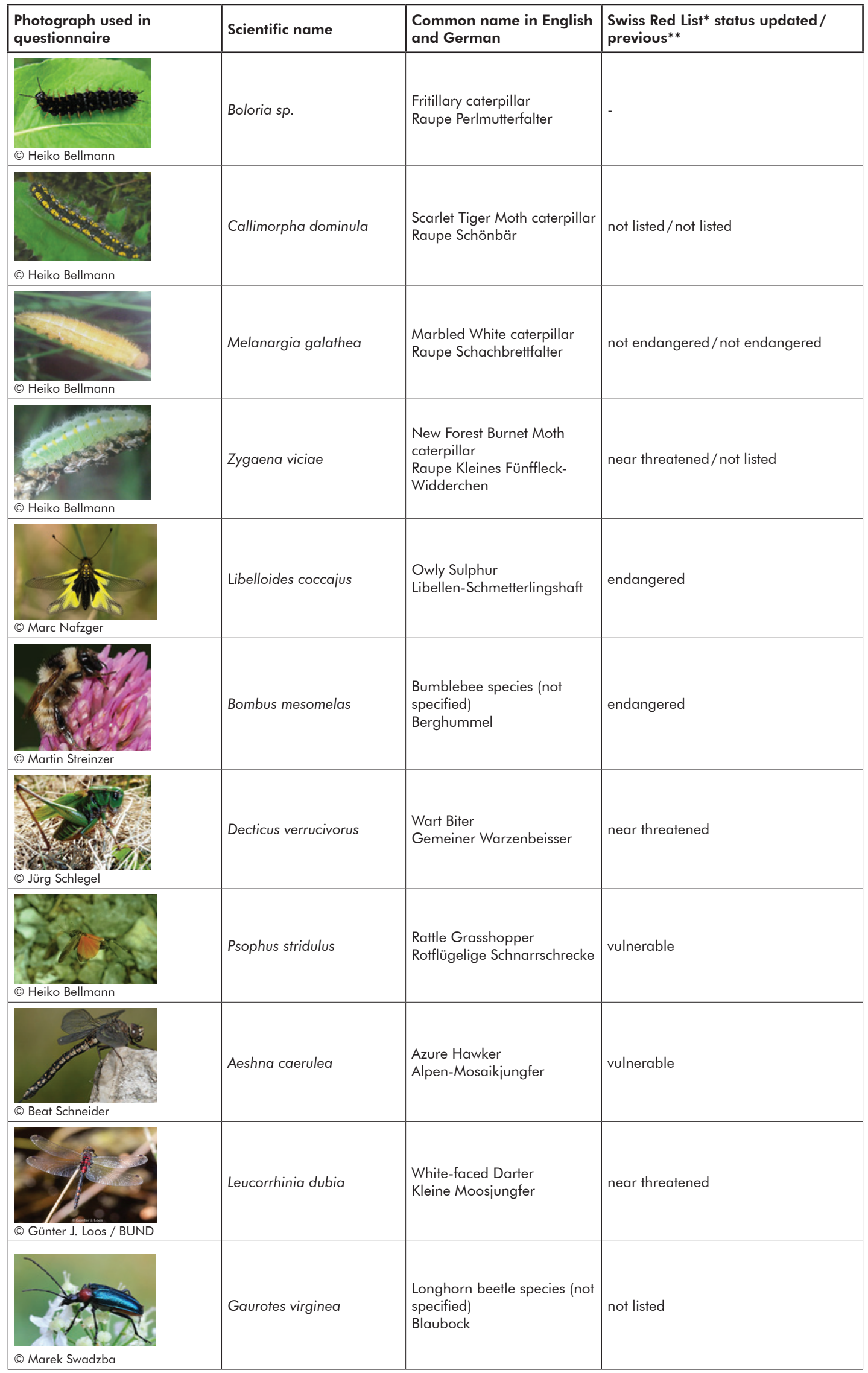

* Source: Wermeille et al. 2014; Monnerat et al. 2007; Gonseth \& Monnerat 2002; Gonseth 1994. ** The updated list for Lepidoptera is autbored by Wermeille et al. 2014. However, the previous Red List by Gonseth 1994 was used in the selection process for adult Lepidoptera. Regarding pre-imaginal Lepidoptera and Coleoptera, Red List status was not considered. *** W bile Callimorpha dominula does not have Red List status, experts believe it to be endangered (BAFU 2011). Hence it was chosen for the survey to represent an adult Lepidoptera species with red colouration.

Note: All photographs as shown in the questionnaires, except for the Glanville Fritillary (Melitaea cinxia), Wart Biter (Decticus verrucivorus) and the White-faced Darter (Leucorrhinia dubia), for which similar photographs were used. 
Colors mentioned as motivation for awarding attitude scores

$\mathrm{n}=4140, *$ Red incl. 17 pink for Moorland Clouded Yellow, **Blue incl. 31 purple for Large Blue

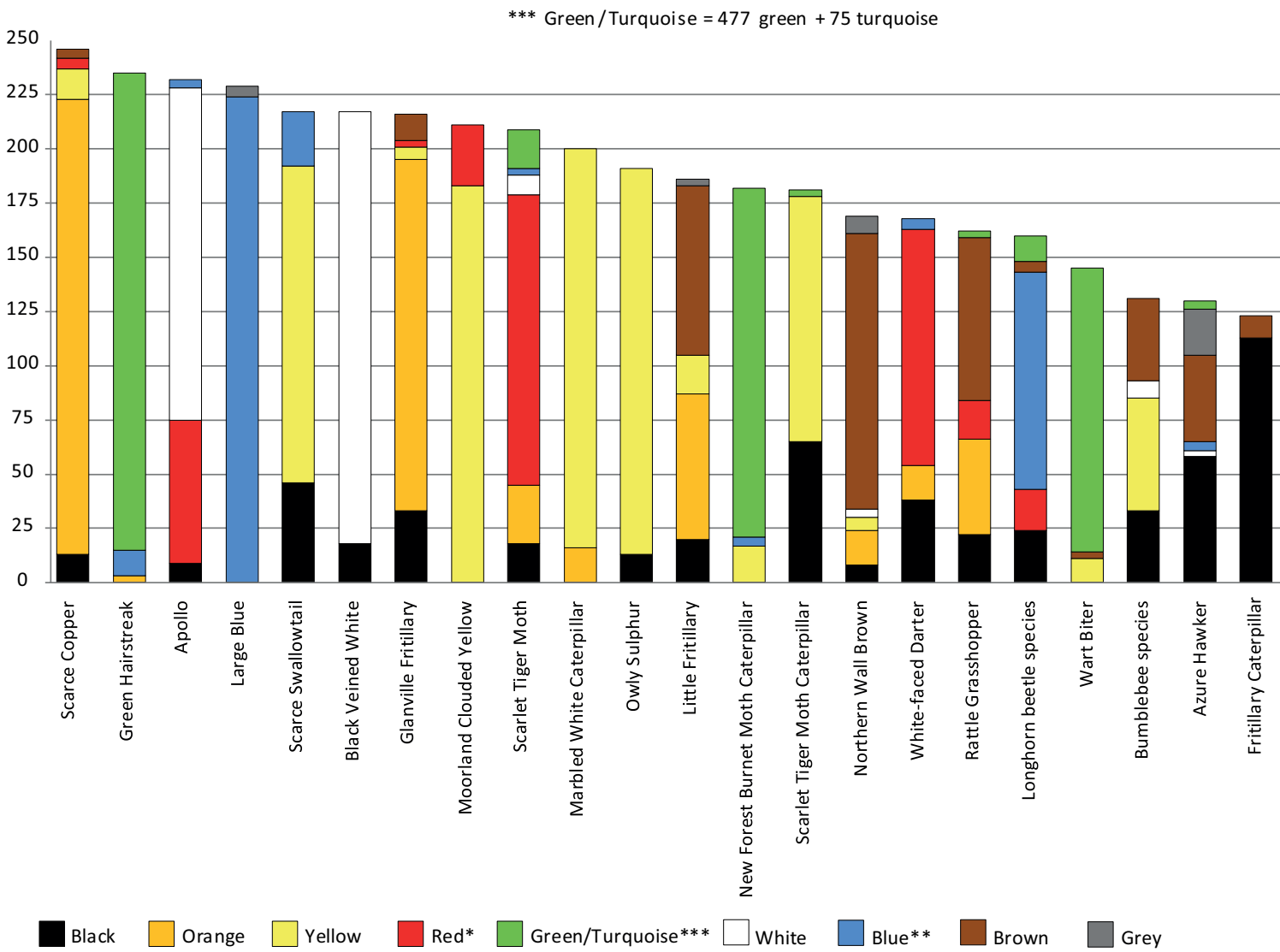

Figure 3 - Number of times colour was mentioned (y-axis) by the 331 pupils as relevant for awarding attitude scores to 11 adult butterflies / moths and 11 other insect species, total sum of mentions $=4140$. Two colours could be named per insect, while not all pupils provided answers on all insects. To simplify the graph, colours with counts $<3$ per species are not shown (80 counts altogether).

- ugly and the interesting - boring categories (Figure 2). Furthermore, the ranking for prettiness covered a wider area of mean score averages and ranged from 2.1-4.6, whereas the average mean score for interesting - boring only ranged from $2.5-3.9$. The significance of the species' ranking order was confirmed (KruskalWallis: p-values $<0.001)$. Also butterflies and other insects formed significantly separate cohorts (Wilcoxon: p-values $<0.001)$.

The 2 darker-coloured (black and black-yellow) caterpillar species, the 2 dragonfly species and the 2 grasshopper species were compared in pairs for significant differences. The pairs share similar body features and ways of movement but differ in pattern and colour. Significant differences were found for the caterpillars selected in all categories (Wilcoxon: p-values $\leq 0.001$ ) and for the dragonflies in all categories (Wilcoxon: $\mathrm{p}$-values $\leq 0.002$ ) except for the interesting - boring category (Wilcoxon: $\mathrm{p}=0.376$ ). The 2 grasshopper species differed significantly from each other in 2 of the 4 categories, i. e. in the category pretty - ugly (Wilcoxon: $\mathrm{p}=0.007)$ and in the category comfortable with - afraid of (Wilcoxon: $\mathrm{p}=0.004$ ) (Table 2).

Gender was confirmed as a significant differentiator in attitudes towards butterflies. The respective mean scores were significantly higher for girls in all categories (Wilcoxon: p-values $<0.001$ ) except comfortable with - afraid of (Wilcoxon: $\mathrm{p}=0.747$ ). When examined for the other insect species, significant gender differences appeared (Wilcoxon: $\mathrm{p}<0.001$ ) except in the category interesting - boring (Wilcoxon: $\mathrm{p}=0.079$ ), as girls tended to rate the non-butterfly species more negatively than boys for the qualities pretty, pleasant and fear-inducing, but not as less interesting (Table 3). Testing by age group, significant differences arose between pre-teens and teenagers in all categories for butterflies and other insects (Wilcoxon: p-values $<0.001$ ).

\section{Discussion}

The 11 butterflies fared well in all categories tested, while the 2 dragonfly species only reached the lower ranks. These findings confirm the intrinsic appeal of butterflies, which symbolize pleasure and beauty in life (Kühn et al. 2008; Lewis et al. 2007). They are in line with Schlegel and Rupf (2010), who also found consistently positive ratings for butterflies and rather negative ones for other insects, but not in complete agreement with statements regarding the positive appeal of dragonflies made by Samways (2013) and Lemelin 
Table 2 - Wilcoxon rank sum test applied to (a) 2 caterpillar species, (b) 2 dragonfly species, and (c) 2 grasshopper species, based on 331 questionnaires.

\begin{tabular}{|l|c|c|c|}
\hline \multirow{2}{*}{ a) Attitude category } & \multicolumn{2}{|c|}{ Mean value } & \multirow{2}{*}{$p$-value } \\
\cline { 2 - 4 } & Fritillary caterpillar (Boloria sp.) & S. Tiger Moth caterpillar (Callimorpha dominula) & \\
\hline pretty - ugly & $2.31(n=325)$ & $3.41(n=325)$ & $p<0.001$ \\
\hline interesting - boring & $2.64(n=324)$ & $3.01(n=322)$ & $p=0.001$ \\
\hline pleasant - disgusting & $2.39(n=323)$ & $2.91(n=323)$ & $p<0.001$ \\
\hline comfortable with - afraid of & $3.09(n=323)$ & $3.48(n=320)$ & $p<0.001$ \\
\hline
\end{tabular}

\begin{tabular}{|l|c|c|c|}
\hline \multirow{2}{*}{ b) Attitude category } & \multicolumn{2}{|c|}{ Mean value } & \multirow{2}{*}{$p$-value } \\
\cline { 2 - 4 } & Azure Hawker (Aeshna caerulea) & White-faced Darter (Leucorrhinia dubia) & \\
\hline pretty - ugly & $2.29(n=329)$ & $2.96(n=325)$ & $p<0.001$ \\
\hline interesting - boring & $2.88(n=326)$ & $2.96(n=325)$ & $p=0.376$ \\
\hline pleasant - disgusting & $2.22(n=327)$ & $2.54(n=324)$ & $p<0.001$ \\
\hline comfortable with - afraid of & $2.85(n=328)$ & $3.17(n=325)$ & $p=0.002$ \\
\hline
\end{tabular}

\begin{tabular}{|l|c|c|c|}
\hline \multirow{2}{*}{ c) Attitude category } & \multicolumn{2}{|c|}{ Mean value } & \multirow{2}{*}{$p$-value } \\
\cline { 2 - 4 } & Rattle Grasshopper (Psophus stridulus) & Wart Biter (Decticus verrucivorus) & \\
\hline pretty - ugly & $2.26(n=327)$ & $2.48(n=326)$ & $p=0.007$ \\
\hline interesting - boring & $2.75(n=326)$ & $2.89(n=324)$ & $p=0.184$ \\
\hline pleasant - disgusting & $2.31(n=323)$ & $2.44(n=324)$ & $p=0.162$ \\
\hline comfortable with - afraid of & $2.94(n=325)$ & $3.24(n=321)$ & $p=0.004$ \\
\hline
\end{tabular}

(2007). Choosing the White-faced Darter (Leucorrbinia dubia) as Dragonfly of the Year for 2014 seems timely and desirable (BUND 2014).

The children's remarks on colours show that they are keen observers. Marginal and contrasting colours were also given as motivation for certain attitude scores (Figure 3). As a result, the colour scores per species appear to reflect the actual colour distribution of the respective animal, with considerable weight at times for the contrasting colour. The red-pink fringe of the Moorland Clouded Yellow (Colias palaeno) accounted for $13 \%$ of its colour scores from the pupils, the orange dots on the abdomen of the White-faced Darter (Leucorrbinia dubia) accounted for 10\%. With butterflies, brightness seemed to be more appreciated than pattern, as can be seen in the slightly lower prettiness ranking of patterned species such as the Scarce Swallowtail (Iphiclides podalirius) and the Scarlet Tiger Moth (Callimorpha dominula). Conspicuous colouring can strongly support positive reactions towards animals, including invertebrates (Prokop \& Fančovičová 2013).

The motivation behind the attitude scores and resulting rankings for the butterflies and the other insects evaluated was examined. Not surprisingly, butterflies were perceived as pretty in the pretty - ugly category mostly for their colour and pattern, and as pleasant in the pleasant - disgusting category because of their body features and movement/sound. Regarding the other insects, colour was an important driver of prettiness, while body features were the major reason for ugliness. In the interesting - boring category, movement/sound and body features had considerable effect on both positive and negative attitudes. Furthermore, negative perception of body and movement/ sound were major reasons for disgust scores (Figure 4). Certain body shapes cause negative associations and infer that the particular insect lives only on and in the ground (Shepardson 2002), which in itself is viewed negatively (Hillman 1988). Insects that creep and crawl on the ground trigger disgust, most probably because of slithery movements or their slimy body surface (Herz 2012). Wet, slimy, oily, gooey and squishy are qualities of consistency and touch that provoke disgust (Miller 1997), which relates to fear of contamination where invertebrates are concerned (Arrindell 2000). It seems reasonable that movement and body are mentioned as disgust causes since disgust is about touch and skin (Miller 2004) and antennae are rather unpopular body features of insects and bugs (Shepardson 2002). These features are symbols of otherness, which is a main driver of disgust (Miller 2004). At the same time, what disgusts can actually be perceived as interesting: "Aversive as it is, but one of the enigmas of disgust lies in the fact that the emotion can also attract; therefore the occasions when it beckons and facilitates are especially intriguing." (Korsmeyer 2011, p. 18)

The differences in attitude scores for the selected pairs of the other insects seemed to be mostly driven by colour (see the dragonfly example in Figure 5). Generally, a yellow-black combination in nature serves as a warning for predators (Braitenberg 2009), while red is an attention-grabbing colour (Gnambs et al. 2010). In 
Reasons given for score awarded in the category pleasant - disgusting
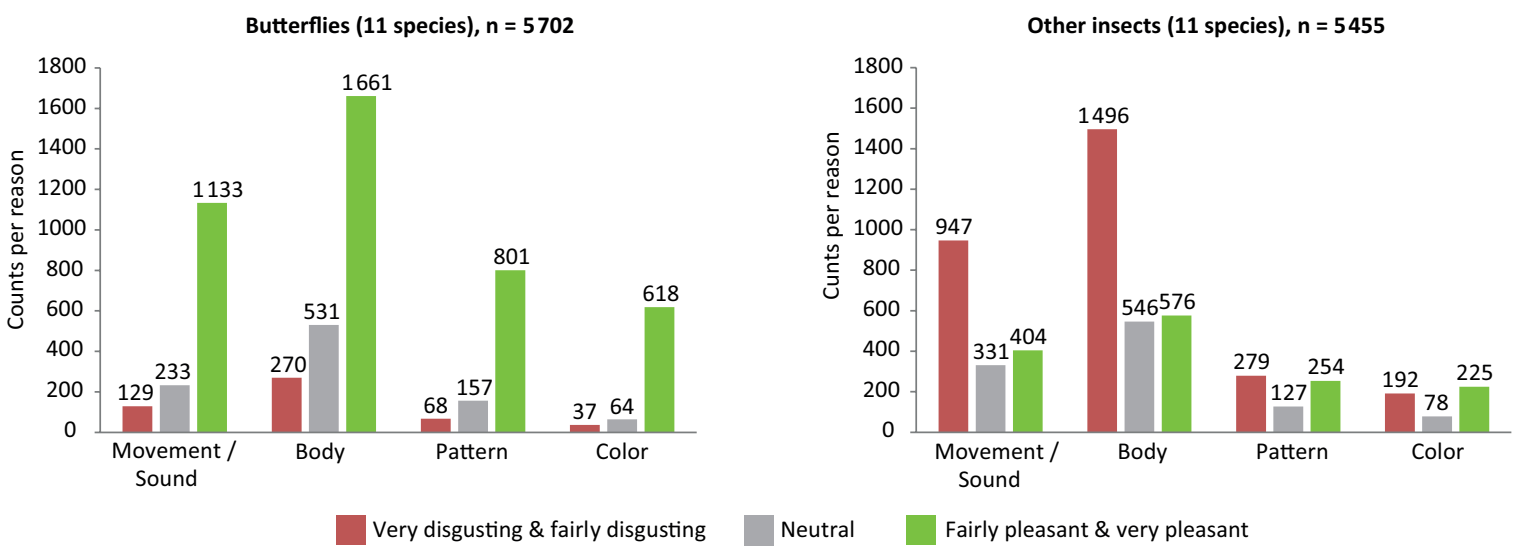

Figure 4 - Number of counts (y-axis) shown as descriptive frequency distribution for the 4 reasons (movement/ sound, body features, pattern and colour) given by the 331 children for awarding attitude scores in the category pleasant - disgusting for the 11 butterfly (adult butterfly / moth) and 11 other insect species. Ticking multiple reasons per category was permitted. To simplify the visualization, the respective counts for very and fairly are combined. Total number of mentions for butterflies $=5702$ and for other insects $=5455$ (not all pupils provided answers to all insects).

\section{Reasons given for score awarded in the category pretty - ugly}
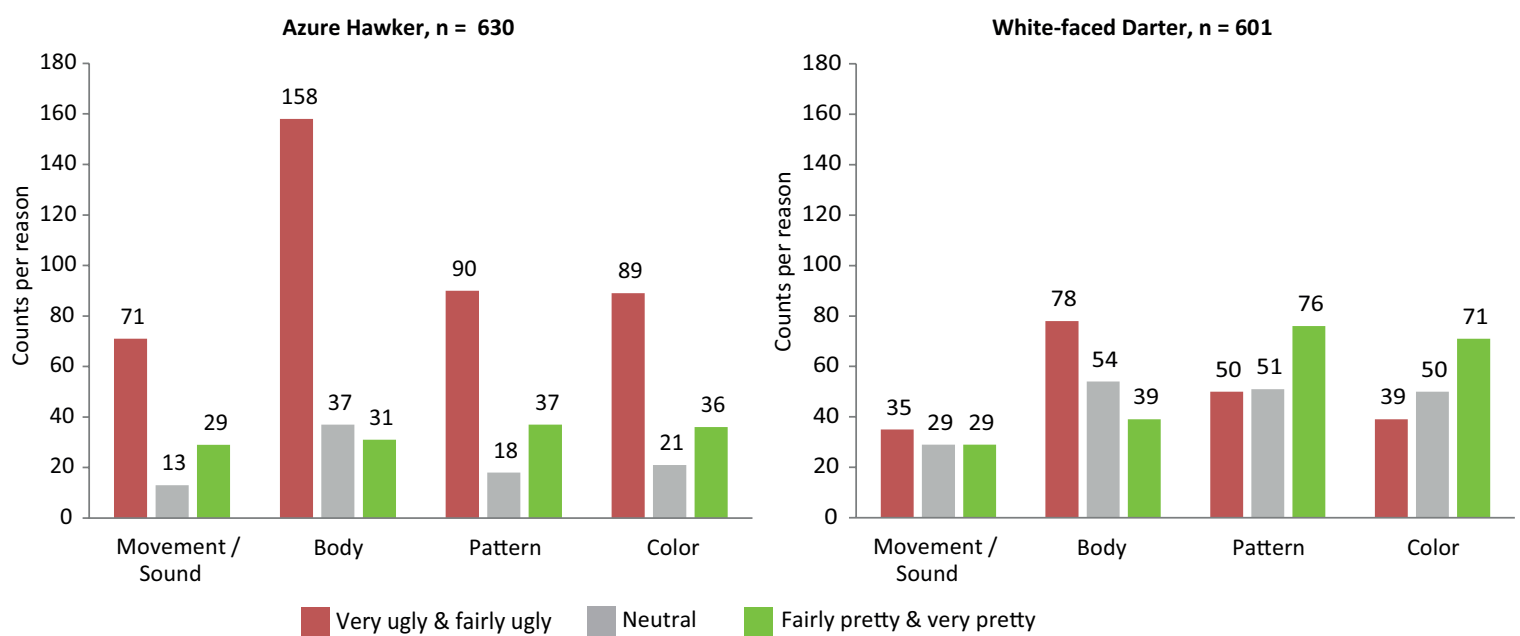

Figure 5 - Number of counts (y-axis) shown as descriptive frequency distribution for the 4 reasons (movement/sound, body features, pattern and colour) given by the 331 children for awarding attitude scores in the category pretty - ugly towards the Azure Hawker (Aeshna caerulea) and White-faced Darter (Leucorrhinia dubia). Ticking multiple reasons per category was permitted. To simplify the visualization, the respective counts for very and fairly are combined. Total number of mentions for Azure Hawker $=630$ and for White-faced Darter $=601$ (not all pupils provided answers to these dragonflies).

our study, the yellow-black pattern of the Scarlet Tiger Moth caterpillar (Callimorpha dominula) gave the species high positive scores when compared to the pure black Fritillary caterpillar (Boloria sp.). Furthermore, due to its red colouring, the White-faced Darter (Leucorrbinia dubia) received higher prettiness scores than the Azure Hawker (Aeshna caerulea). Aposematic species are more likely to trigger positive emotions than duller or colourless species (Prokop \& Fančovičová 2013). However, the pupils' reasons did not offer further explanation for the differences in their rankings of the 2 grasshoppers.

Gender differences were found as girls awarded higher positive scores than boys towards butterflies, in line with Schlegel et al. (submitted). The comfortable with - afraid of category was an exception, most probably because butterflies generally do not induce fear. Tikka et al. (2010) showed that female students have more positive attitudes towards nature. At the same time, the lower scores that female pupils awarded to the other insects in our study were in line with research in which girls rated invertebrates unfavourably, perceiving them as less lovable, as disgusting or threatening (Prokop \& Fančovičová 2013; Schlegel \& Rupf 2010; Kellert 1993). Our findings build on those of Schlegel et al. (submitted), who identified 8 male species that gained significantly higher attitude scores from boys than from girls, the higher scores 
possibly being driven by the boys' lower perception of fear and disgust, and higher perception of beauty.

Pre-teens generally showed more enthusiasm than older age groups and awarded the highest scores more frequently. We looked at the motivations for the Scarce Swallowtail (Iphiclides podalirius) and the bumblebee species (Bombus mesomelas) to better understand the significant differences in attitude scores between preteens and teenagers. $35 \%-80 \%$ of the scores awarded by pre-teens were very positive scores, while the teenagers' scores were more prominently in the fairly positive value range. An even more precise picture emerged for the bumblebee, as teenagers gave only few very positive scores and very negative ones occurred in substantially higher numbers. Lindemann-Matthis (2006) worked with children aged 8-16 and described how interest in activities with plants and animals continuously decreased with age, while preference for outdoor education increased. Also, our findings are in line with Kellert (2002), who showed that children between 6 and 12 years of age relate to the physical attraction of nature (aesthetic value), form an emotional bond with it (humanistic value), are curious about the differentness of nature, and are keen to gain an understanding of it (knowledge value). Teenagers aged 13-17 relate to nature on ethical grounds (moralistic value), want to discover nature (naturalistic value) and understand its ecology (scientific value). As our questionnaire was also used by 8 -year olds, it had a simple design that might not have provided enough opportunity for older pupils to give fuller information.

\section{Outlook}

The aim of our study was to provide a quantitatively based rationale for selecting insects as flagship species for the major habitats in Beverin Nature Park. While our intention is not to recommend a particular insect species at this point, we can provide a better understanding of motivational aspects driving attitudes to insects. Prettiness is a significant driver; colour is important and can help to overcome negative attitudes towards insects. Body features are a further major driver of both positive as well as negative attitudes, especially in terms of pleasantness or disgust.

However, especially for insect species other than butterflies, their interesting aspects should be exploited and promoted more intensively as interest fosters knowledge, which in turn positively affects attitudes (Tikka et al. 2010; Arnold 2002; Boeck Yore \& Boyer 1997). As shown by the rankings, interest is of importance and scored higher than prettiness at the lower end.

Environmental education could change attitudes towards insects by use of storytelling (changingminds. org 2013), a strategy increasingly applied in campaign management and PR (Herbst 2008). Originality is a relevant aspect of fauna (UNA 2011), which could be
Table 3 - Significance of gender differences in the respective attitude categories tested for (a) 11 butterfly species and (b) for 11 other insects with the Wilcoxon rank sum test, based on 331 questionnaires.

\begin{tabular}{|l|c|c|l|}
\hline \multirow{2}{*}{ Attitude category } & \multicolumn{2}{|l|}{ Mean value } & \multirow{2}{*}{ p-value } \\
\cline { 2 - 4 } & Girls (n=167) & Boys (n=164) & \\
\hline a) Butterflies & 4.40 & 4.25 & $\mathrm{p}<0.001$ \\
\hline pretty - ugly & 3.84 & 3.41 & $\mathrm{p}<0.001$ \\
\hline interesting - boring & 4.12 & 3.90 & $\mathrm{p}<0.001$ \\
\hline pleasant - disgusting & 4.22 & 4.21 & $\mathrm{p}=0.747$ \\
\hline comfortable with - afraid of & & \multicolumn{2}{|l}{} \\
\hline b) Other insects & 2.68 & 2.99 & $\mathrm{p}<0.001$ \\
\hline pretty - ugly & 2.90 & 2.98 & $\mathrm{p}=0.079$ \\
\hline interesting - boring & 2.30 & 2.73 & $\mathrm{p}<0.001$ \\
\hline pleasant - disgusting & 2.85 & 3.42 & $\mathrm{p}<0.001$ \\
\hline comfortable with - afraid of & &
\end{tabular}

leveraged more effectively by using drama in a narrative with a climax. Examples for exercising metamorphosis or underdog plots (Tobias 1993) could be the Large Blue (Maculinea arion) with its dependency on Myrmica ants (Lepidopterologen-Arbeitsgruppe 1994), or the Rattle Grashopper (Psophus stridulus) with its suggestion of a hero when flying and exposing its red hindwings. The stories should be told in such a way that the recipients can relate to them (Blaustone 1992), include an element of surprise or humor (Gálvez 2012), and inspire people to action (Woodside et al. 2008). Storytelling has motivated girls to take on previously unpopular tasks and is therefore powerful (Kelleher et al. 2007). Thus storytelling could be used to possibly overcome overt as well as subliminal disgust.

As children tend to become more critical and less enthusiastic with age, environmental education should start early (White 2004; Wilson 1996). The Beverin nature experience programmes should include selfexperience and discovery themes on ecology to cater especially for teenagers (Bögeholz 2006; Chawla 2006; Herrmann 2004; Kellert 2002).

To give visitors of all ages a real life experience and to decide which story to tell and how (e.g. through signage or via treasure-hunt-type sign posts), Beverin Nature Park needs to ascertain which areas of the park the respective insects inhabit. A second research project should be launched to determine where the candidates can be experienced from existing paths and hiking routes or from future nature education trails in the Schams Mountain region.

A final decision on the choice of insect as the flagship species seems feasible based on both the observation data and the attitude data gained in this study.

\section{Acknowledgements}

We would like to express our gratitude to those who supported this study. In particular, we would like 
to thank Erica Nicca and Remo Kellenberger (Beverin Nature Park Wergenstein) for their trust and cooperation. Our thanks also go to Simon Capt (CSCF Neuchatel), Claudia Huber (UNA Bern), Heidi Schuler and Norbert Danuser (ANU Graubünden), who provided helpful data and insightful reports; to Carola Piazolo (Johannes Schule Bildstock) and Eicke von Lindern (Uppsala Universitet), who reviewed early versions of the questionnaire; to Peter Kauf, Patrik Wiedemeier and Maggi Lussi Bell (ZHAW Wädenswil), who shared important and detailed insights into statistical analysis, insect habitats and proof-reading respectively. We are especially grateful to the teachers in Andeer, Bonaduz, Rhäzüns, Rodels, Sils, Splügen, Thusis and Zillis for allowing their pupils to complete the questionnaires during class time. Our sincere thanks also go to the pupils who answered our questions so diligently, both in the final and in the pre-test version.

\section{References}

Arnold, M. 2002. Aspekte einer modernen Neurodidaktik. München.

Arrindell, W.A. 2000. Phobic dimensions: IV. The structure of animal fears. Behaviour research and therapy 38 (5): 509-530.

BAFU 2011: Liste der National Prioritären Arten. Arten mit nationaler Priorität für die Erhaltung und Förderung, Stand 2010. Bern.

Ballouard, J.-M, F. Brischoux \& X. Bonnet 2001. Children prioritize virtual exotic biodiversity over local biodiversity. PLOS ONE 6 (8): 23152.

Balmford, A., L. Clegg, T. Coulson \& J. Taylor 2002. Why conservationists should heed Pokemon. Science 295(5564):2367.

Barua, M., D.J. Gurdak, R. Akhtar Ahmed \& J. Tamuly 2012. Selecting flagships for invertebrate conservation. Biodiversity Conservation 21 (6): 1457-1476.

Bednar-Friedl, B., B. Gebetsroither \& M. Getzner 2009. Willingness to Pay for Species Conservation Programs: Implications for National Park Funding, eco.mont 1 (1): 9-14.

Bellmann, H. 2003. Der neue Kosmos SchmetterlingsFührer. Schmetterlinge, Raupen, Futterpflanzen. Stuttgart.

Berenbaum, M. 2008. Insect conservation and the entomological society in America. American Entomologist 54 (2): 117-120.

Black, S.H., M. Shepard \& M.M. Allen 2001. Endangered invertebrates: the case for greater attention to invertebrate conservation. Endangered Species Update 18 (2): 42-50.

Blaustone, B. 1992. Teaching evidence: storytelling in the classroom. American University Law Review 41: 453-484.

Boeck Yore, L. \& S. Boyer 1997. College student's attitudes towards living organisms: The influence of experience and knowledge. The American Biology Teacher 59: 558-563.
Bögeholz, S. 2006. Nature experience and its importance for environmental knowledge, values and action: recent German empirical contributions. Environmental Education Research 12 (1): 65-84.

Bowen-Jones, E. \& A. Entwistle 2002. Identifying appropriate flagship species: the importance of culture and local context. Oryx 36 (2): 189-195.

Braitenberg, V. 2009. Das Bild der Welt im Kopf. Eine Naturgeschichte des Geistes. Stuttgart.

BUND 2014. Libelle des Jahres 2014 ist die Kleine Moosjungfer. Available at: http://www. bund.net/themen_und_projekte/biologische_ vielfalt/libellenschutz/libelle_des_jahres_2014/ (accessed 24/02/14)

changingminds.org 2013. How we change what others think, feel, believe and do. Available at: http://changingminds.org/disciplines/storytelling/ storytelling.htm (accessed 30/01/14)

Chawla, L. 2006. Learning to love the natural world enough to protect it. Barn 2: 57-78.

Dennis, R.L.H., T.G. Shreeve \& D.A. Sheppard 2007. Species conservation and landscape management: A habitat perspective. In: Stewart, A.J.A., T.R. New \& O.T. Lewis (eds.), Insect Conservation Biology: 92-126. Wallingford.

Forster, S., R. Kellenberger \& W. Tischhauser 2008. Naturpark Beverin. Management Plan für die Errichtungsphase. Available at: http://www. naturpark-beverin.ch/images/content/downloads_ wissenspool/Managementplan_RNP-Beverin.pdf. (accessed: 10/10/13)

Gálvez, C. 2012. 30 Minuten Storytelling. Offenbach.

Genovart, M., G. Tavecchia, J.J. Ensenat \& P. Laiolo 2013. Holding up a mirror to the society: children recognize exotic species much more than local ones. Biological Conservation 159: 484-489.

Gnambs, T., M. Appel \& B. Batinic 2010. Color red in web-based knowledge testing. Computers in Human Behavior 26 (6): 1625-1631.

Gonseth, Y. 1994. Rote Liste der gefährdeten Tagfalter der Schweiz. In: Duelli, P. et al. (eds.), Rote Liste der gefährdeten Tierarten der Schweiz: 48-51. Bern.

Gonseth, Y. \& C. Monnerat 2002. Rote Liste der gefährdeten Libellen der Schweiz. Bern.

Guiney, M.S. \& K.S. Oberhauser 2008. Insects as flagship conservation species. Terrestrial Arthropod Reviews 1 (2): 111-123.

Hammond, P.M. 1995. The current magnitude of biodiversity. In: Heywood, V.H. \& R.T. Watson (eds.), Global Biodiversity Assessment: 113-137. Cambridge.

Herbst, D. 2008. Storytelling. Konstanz.

Herrmann, U. 2004. Gehirnforschung und die Pädagogik des Lehrens und Lernens: Auf dem Weg zu einer „Neurodidaktik“? Zeitschrift für Pädagogik 50 (4): 471-474.

Herz, R. 2012. That's Disgusting. Unraveling the Mysteries of Repulsion. New York.

Hillman, J. 1988. Going bugs. Spring: A Journal of Achetype and Culture: 40-72. 
Jamieson, S. 2004. Likert scales: how to (ab)use them. Medical Education 38: 1217-1218.

Kelleher, C., R. Pausch \& S. Kiesler 2007. Storytelling Alice Motivates Middle School Girls to Learn Computer Programming. Programming by and with end users: $1455-1464$.

Kellert, S.R. 2002. Experiencing nature: affective, cognitive, and evaluative development in children. In: Kahn, P.H.J. \& S.R. Kellert (eds.), Children and nature. Psycholocial, sociocultural and evolutionary investigations: 117151. Cambridge, Massachusetts.

Kellert, S.R. 1993. Values and perceptions of invertebrates. Conservation Biology 7 (4): 845-855.

Knegtering, E., L. Hendrickx, H.J. van der Windt \& A.J.M. Schoot Uiterkamp 2002. Effects of species characteristics on nongovernmental organizations' attitudes toward species conservation policy. Environment and Behaviour 34 (3): 378-400.

Korsmeyer, C. 2011. Savoring disgust: The foul and the fair in aesthetics. New York.

Kühn, E., R. Feldmann, A. Harpke, N. Hirneisen, M. Musche, P. Leopold \& J. Settele 2008. Getting the public involved in butterfly conservation: lessons learned from a new monitoring scheme in Germany. Israel Journal of Ecology and Evolution 54: 89-103.

Lant, B. 2013. Equidistance of likert-type scales and validation of inferential methods using experiments and simulations. The Electronic Journal of Business Research Methods 11 (1): 16-28.

Lemelin, R.H. 2007. Finding beauty in the dragon: the role of dragonflies in recreation and tourism. Journal of Ecotourism 6: 139-145.

Lepidopterologen-Arbeitsgruppe 1994. Tagfalter und ibre Lebensräume. Arten - Gefährdung - Schutr. Schweiz. und angrenzende Gebiete. Basel.

Lewis, O.T., T.R. New \& A.J.A. Stewart 2007. Insect conservation: progress and prospect. In: Stewart, A.J.A., T.R. New \& O.T. Lewis (eds.), Insect conservation biology: 431-436. Wallingford.

Lindemann-Matthies, P. 2006. Investigating nature on the way to school: responses to an educational programme by teachers and their pupils. International Journal of Science of Education 28 (8): 895-918.

Losey, J.E. \& M. Vaughan 2008. Conserving the ecological services provided by insects. American Entomologist 54 (2): 113-115.

Miller, S.B. 2004. Disgust: The gatekeeper emotion. Hillsdale, New Jersey.

Miller, W.I. 1997. The anatomy of disgust. Cambridge, Massachusetts.

Monnerat, C., P. Thorens, T. Walter \& Y. Gonseth 2007. Rote Liste der gefährdeten Heuschrecken der Schweiz. Bern.

Mora, C., D.P. Tittensor, S. Adl, A.G.B. Simpson \& B. Worm 2011. How many species are there on earth and in the ocean? PLoS Biol 9 (8): doi:10.1371/journal. pbio. 1001127
Munoz, J. 2007. Biodiversity conservation including uncharismatic species. Biodiversity Conservation 16: 2233-2235.

Prokop, P. \& J. Fančovičová 2013. Does colour matter? The influence of animal warning colouration on human emotions and willingness to protect them. Animal conservation 16: 1-9.

R Foundation of Statistical Computing 2013. The R-Project. Available at: http:/ /www.r-project.org/ (accessed: 3/11/2013)

Randler, C., E. Hummel \& P. Prokop 2012. Practical work at school reduces disgust and fear of unpopular animals. Society \& Animals 20: 61-74.

Samways, M.J., N.E. Stork, J. Cracraft, H.A.C. Eeley, M. Foster, G. Lund \& C. Hilton-Taylor 1995. Scales, planning and approaches to inventoring and monitoring. In: Heywood, V.H. \& R.T. Watson (eds.), Global Diversity Assessment. 475-517. Cambridge, UK.

Samways, M.J. 2013. Dragonflies: their lives, our lives, from ponds to reserves. In: Lemelin, R.H. (ed), The Management of Insects in Recreation and Tourism: 108119. New York.

Schlegel, J. \& R. Rupf 2010. Attitudes towards potential animal flagship species in nature conservation: A survey among students of different educational institutions. Journal for Nature Conservation 18 (4): 278290.

Schlegel, J., G.B. Breuer \& R. Rupf (2015, in press). Local insects as flagship species to promote nature conservation? A survey among primary school children on their attitudes towards invertebrates.

Shardlow, M. 2013. The institutionalization of insect welfare: The cultural aspects of establishing a new organization dedicated to conserving invertebrates. In: Lemelin, R.H. (ed), The Management of Insects in Recreation and Tourism: 274-288. New York.

Shepardson, D.P. 2002. Bugs, butterflies, and spiders: children's understandings about insects. International Journal of Science of Education 24 (6): 627-643.

Simberloff, D. 1998. Flagships, umbrellas, and keystones: Is single-species management passé in the landscape era? Biological Conservation 83 (3): 247-257.

Tikka, P.M., M.T. Kuitunen \& S.M. Tynys 2010. Effects of educational background on students' attitudes, activity levels, and knowledge concerning the environment. The Journal of Environmental Education 31 (3): 12-19.

Tobias, R.B. 1993. 20 master plots (and how to build them). Cincinnati, Ohio.

UNA 2011. Arten- und Lebensraumförderung im regionalen Naturpark Beverin. Naturpark. Zielarten und prioritäre Naturpark Lebensräume. Bern.

Walpole, M.J. \& N. Leader-Williams 2002. Tourism and flagship species in conservation. Biodiversity and Conservation 11: 543-547.

Weiss, M. 2012. Fear and its opposites in the history of emotions. In: Laffan, M. \& M. Weiss (eds.), Facing 
Fear: The History of an Emotion in Global Perspective: 1-9. Princeton, New Jersey.

Wermeille E., Y. Chittaro \& Y. Gonseth 2014. Rote Liste Tagfalter und Widderchen. Gefäbrdete Arten der Schweiz: Bern.

White, R. 2004. Young children's relationship with nature: Its importance to children's development \& the earth's future. Available at: http:// www.whitehutchinson.com/children/articles / childrennature.shtml (accessed 12/12/12).

Wilson, R. 1996. Starting early: Environmental education during the early childhood years. ERIC DIGEST. ERIC Clearinghouse for Science Mathematics and Environmental Education.

Woodside, A.G., S. Sood \& K.E. Miller 2008. When consumers and brands talk: Storytelling theory and research in psychology and marketing. Psychology \& Marketing 25 (2): 97-145.

\section{Authors}

Reto Rupf

Professor of environmental planning at the Institute of Natural Resource Sciences IUNR at Zurich
University of Applied Sciences ZHAW, Grüental, 8820 Wädenswil. Research topics: human-wildlife interactions, outdoor recreation, recreation ecology, parks, visitor management, environmental management, and EIA. Email: reto.rupf@zhaw.ch

\section{Jürg Schlegel}

Lecturer of conservation ecology and entomology at the Institute of Natural Resource Sciences IUNR at Zurich University of Applied Sciences ZHAW, Grüental, 8820 Wädenswil. Research topics: succession of insects in dynamic landscapes; insect-environment-interactions; flagship species approach; applied conservation ecology based on target species concept. Email: juerg.schlegel@zhaw.ch

\section{Gabriele B. Brever}

Research assistant at the Institute of Natural Resource Sciences IUNR at Zurich University of Applied Sciences ZHAW, Grüental, 8820 Wädenswil. Special interest: biodiversity and applied conservation ecology based on interdisciplinary approaches. Email: gabriele_breuer@yahoo.de 